\title{
Introduction: Structure of Scientific Revolutions, 50 Years On
}

\author{
Rogier De Langhe
}

Published online: 12 February 2013

(C) Springer Science+Business Media Dordrecht 2013

Thomas Kuhn's Structure of Scientific Revolutions is a book that philosophers love to hate. With over a million copies sold it is one of the most popular books in twentieth century philosophy, yet most work in philosophy of science has been aimed at dismissing or at least modifying Kuhn. On the other hand, and much to Kuhn's own horror, "social studies of science" have embraced Kuhn's alleged skeptical consequences. In the 1990's these opposing views between realists and constructivists collided in a disciplinewide debate called the "Science Wars". After the turn of the century, however, interest in Kuhn's ideas seems to have waned. The topics got old and perhaps philosophers just grew tired of looking back. With no synthesis in sight, the relative calm suggests they agreed to disagree, leaving the discipline in a state of fragmentation. Now that the new century is well under way, the 50th anniversary of Kuhn's Structure of Scientific Revolutions is a good occasion to look ahead and ask what the role of Kuhn's legacy can be in twenty first century philosophy of science.

This issue of Topoi addresses this question with a mix of tradition and innovation. It brings together contributions by senior scholars who have themselves, like Kuhn, helped shape twentieth century philosophy of science, and young academics on whom the burden falls of shaping that of the 21 th. Their contributions fall into two groups, those looking to refine Kuhn's ideas and those ready to implement them.

Hanne Andersen extends Kuhn's "Essential Tension" between tradition and innovation within mono-disciplinary

R. De Langhe $(\square)$

Tilburg Center for Logic and Philosophy of Science (TiLPS), Tilburg University, Warandelaan 2, PO Box 90153,

5000 LE Tilburg, The Netherlands

e-mail: rogierdelanghe@gmail.com science with a complementary tension between intellectual dependence and critical scrutiny versus epistemic dependence and trust in interdisciplinary science. Dunja Šešelja and Christian Straßer develop Kuhn's account of theory choice based on the evaluation of pursuit worthiness. They argue that dropping the account of epistemic semantic monism inherent in Kuhn's ideas will yield richer notions of persuasion, interpretation and pluralism. William Rehg provides an interpretation of Kuhn's ideas in terms of collective intentionality and argues this allows to save Kuhn's conception of normal and revolutionary science without having to rely on meaning holism and incommensurability. Howard Sankey proposes to sharpen Kuhn's account by adding to Kuhn's later rejection of methodological incommensurability a particularist and naturalist conception of epistemic normativity in order to take away the sceptical basis for epistemic relativism. Jerry Doppelt asks what form of realism is still possible given Kuhn's characterization of the process of theory change. In response to this challenge he develops and defends a 'best current theory' realism. While Ronald Giere argues that Kuhn's later position is in line with his own account of perspectival realism.

Visions for the future implementation of Kuhn's ideas are developed in different directions. Some articles see Kuhn's future as offering a new paradigm for philosophy of science, others see it as a bridge between philosophy and other fields or as a tool with applications to specific philosophical problems. Joseph Rouse calls attention to a number of less commonly recognized aspects of Kuhn's work. Some of them indicate that Kuhn was an important precursor to subsequent philosophical developments. But Rouse also looks ahead and cites three overlooked themes that hold opportunities for future research, insisting that the Kuhnian revolution in philosophy of science still has to 
occur. Rogier De Langhe explains the failure of the Kuhnian paradigm by its lack of articulation and points to three recent developments that could finally operationalize it. He concludes by outlining a research agenda for a systemic philosophy of science. K. Brad Wray envisions a Kuhnian research agenda exploring scientific specialization. In particular, a better understanding of disciplinary formation is a task that was anticipated in Kuhn's later writings and prompts interesting and novel questions that still need to be addressed systemically. Vasso Kindi argues that the lasting contribution of Kuhn has been to lay out an entirely new research programme in which scientific practices cannot be understood independently of the historical and sociological conditions that make them possible. This claim does not hinge on particular empirical results from history or sociology, rather it constitutes a new way of looking at science, the presuppositions of which are themselves not open for debate but rather defining their perspective. Also JouniMatti Kuukkanen takes as a starting point Kuhn's pivotal role in connecting historical and philosophical studies of science and suggests three main strands for future research that will increase the mutual relevance of history and philosophy. William Goodwin shows the relevance of Kuhns ideas for current discussions on disagreement. Kuhn's views include, but are not limited to, revolutionary disagreement. Using several examples he illustrates how a Kuhnian framework containing both non-revolutionary and revolutionary disagreement provides a powerful tool to analyze scientific controversies. Alexandra Bradner uses the metaethical debate between justice and care to demonstrate how she sees the role of Kuhn's theory as a metaphilosophical frame for understanding otherwise intractable philosophical debates. 